\title{
Medievalista
}

Online

$27 \mid 2020$

Número 27

\section{Novas responsabilidades para o IEM e para a Medievalista}

\section{A Redacção}

\section{(2) OpenEdition}

\section{Journals}

\section{Edição electrónica}

URL: http://journals.openedition.org/medievalista/2777

DOI: 10.4000/medievalista.2777

ISSN: 1646-740X

\section{Editora}

Instituto de Estudos Medievais - FCSH-UNL

\section{Refêrencia eletrónica}

A Redacção, "Novas responsabilidades para o IEM e para a Medievalista », Medievalista [Online], 27 | 2020, posto online no dia 01 janeiro 2020, consultado o 23 setembro 2020. URL : http:// journals.openedition.org/medievalista/2777 ; DOI : https://doi.org/10.4000/medievalista.2777

Mediavalista está licenciado com uma Licença Creative Commons - Atribuição-NãoComercial 4.0 Internacional. 
Título / Title (Português e Inglês): Novas responsabilidades para o IEM e para a Medievalista

Autor(es) / Author(s): A Redacção

Fonte: Medievalista [Em linha]. Direc. Bernardo Vasconcelos e Sousa. Lisboa: IEM. Disponível em:

http://www2.fcsh.unl.pt/iem/medievalista/MEDIEVALISTA27/editorial27 ISSN: 1646-740X 


\title{
Editorial: Novas responsabilidades para o IEM e para a
}

\section{Medievalista}

\author{
A Redacção
}

No anterior número da Medievalista, colocado online no dia 1 de Julho de 2019, referimos no Editorial que estava para breve o anúncio, por parte da Fundação para a Ciência e a Tecnologia (FCT), dos resultados do processo de avaliação das Unidades de Investigação portuguesas. E, de facto, ainda nesse mês vieram a ser divulgadas as classificações dos Centros, atribuídas por painéis de especialistas estrangeiros.

No caso do Instituto de Estudos Medievais (IEM), o trabalho realizado no período 20142017 e o Projecto Estratégico proposto para 2019-2022 mereceram a classificação de "Excelente". É um resultado que honra o IEM, a sua Direcção e todos os que nele desenvolvem a sua acção e que assim vêem reconhecido o seu esforço e a qualidade das iniciativas e da investigação produzidas. Mas é também um factor de acrescida responsabilidade para o nosso Instituto, para o conjunto e para cada um dos seus membros. O aumento do financiamento público que é consequência da passagem da classificação anterior ("Muito Bom") para a agora atribuída, não autorizando extravagâncias, permitirá algum desafogo face a passados constrangimentos, quer na investigação fundamental, quer, por exemplo, no funcionamento desta nossa revista.

E a Medievalista não se faz rogada, como a sua edição semestral regular e mais este número o comprovam. Além do Destaque dedicado a um estudo de Peter Edbury sobre a tradução francesa da Historia de William of Tyre que foi feita na época da extinção da Ordem do Templo, a secção dos Artigos inclui trabalhos de Inês Olaia sobre "O Rei que Esmorece", de Marco Sousa Santos e Daniel Santana sobre "O Cruzeiro Medieval de 
Tavira", de Joseph T. Snow sobre "Mary's Role in the Repudiation of Their Beliefs of Pagans, Jews and Moors", de Hilário Franco Júnior sobre "A Serpente, Espelho de Eva. Iconografia, Analogia e Misoginia em Fins da Idade Média”, de Santiago Barreiro sobre "El País de onde Vienen los Monstruos...". e de Duarte de Babo Marinho sobre “A diplomacia e os diplomatas na baixa Idade Média portuguesa (1431-1475)”.

Nas Recensões António Rei, Mariña Bermúdez Beloso e Francisco Pato de Macedo passam em revista três livros recentemente saídos e que vale a pena conhecer. A secção Apresentação de Teses revela-nos, pela pena dos respectivos Autores, o conteúdo da tese de doutoramento de Margarida Leme, da dissertação de mestrado de Diogo Cardoso Gomes e da lição proferida por Philippe Josserand no âmbito de uma prova superior de progressão na carreira académica, realizada em França (a Habilitation), com um ensaio original e entretanto publicado sobre Jacques de Molay, o último mestre templário. Na Varia, Miguel Metelo de Seixas faz o balanço do Curso Livre que decorreu no Mosteiro da Batalha subordinado ao tema "No tempo de D. João I", Adelaide Miranda e Isabel Barros Dias relatam a Homenagem de que foi alvo o Professor Aires Nascimento e, finalmente, Paulo Catarino Lopes escreve sobre a mais recente edição do Seminário José Mattoso.

A propósito deste medievalista que é referência central do IEM, tendo também desempenhado durante anos o cargo de Director desta revista, é com enorme júbilo que assinalamos aqui o "Prémio Árvore da Vida - Padre Manuel Antunes", que lhe foi atribuído em 2019 pelo Secretariado Nacional da Pastoral da Cultura. O prémio, que vai na sua $15^{\mathrm{a}}$ edição, visa assinalar percursos humanos e obras que se destaquem em áreas do conhecimento, da criatividade artística ou da acção social e que reflictam valores humanos e cristãos considerados fundamentais pela entidade instituidora. Este prémio junta-se, assim, a tantos outros com que Mattoso tem sido distinguido ao longo da sua carreira de historiador e entre os quais se destaca o "Prémio Pessoa", na sua primeira edição, em 1987. A Redacção da Medievalista saúda vivamente José Mattoso, o nosso "sempre Director", por mais este justo reconhecimento de uma obra historiográfica e de uma atitude intelectual e cívica de referência para todos nós. 


\section{COMO CITAR ESTE ARTIGO}

\section{Referência electrónica:}

Redacção - "Novas responsabilidades para o IEM e para a Medievalista". Medievalista 27 (Janeiro - Junho 2020) . [Em linha] [Consultado dd.mm.aaaa]. Disponível em http://www2.fcsh.unl.pt/iem/medievalista/MEDIEVALISTA27/editorial27 ISSN 1646-740X.

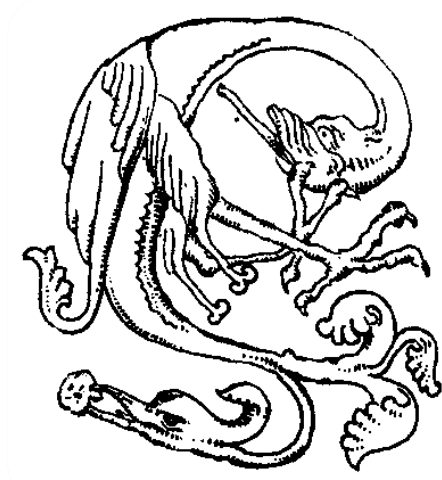

